\title{
Lack of genetic differentiation between anadromous and resident sympatric brown trout (Salmo trutta) in a Normandy population
}

\author{
Katia Charles $^{1, a}$, René Guyomard ${ }^{2}$, Björn Hoyheim ${ }^{3}$, Dominique Ombredane ${ }^{1}$ and Jean-Luc Baglinière ${ }^{1}$ \\ 1 UMR INRA-Agrocampus Rennes Ecobiologie et Qualité des Hydrosystèmes Continentaux, 65 rue de St Brieuc, \\ 35042 Rennes Cedex, France \\ 2 INRA Laboratoire de Génétique des Poissons, Domaine de Vilvert, 78352 Jouy-en-Josas, France \\ 3 Norwegian School of Veterinary Science, Ullevålsveien 72 Oslo, Norway
}

Received 30 April 2004; Accepted 17 January 2005

\begin{abstract}
The level of genetic differentiation between anadromous and non-andromous trout (Salmo trutta L.) coexisting in a Norman river (Oir river) was examined at 15 microsatellites markers. Despite a large amount of variation, no genetic differentiation was found between forms. Four domesticated stocks were also genotyped with the same loci. Highly significant differences were found with natural samples allowing to exclude a recent stocking effect on the Oir population. We conclude that the resident and anadromous trout form a single naturally reproducing unit in this river system. However, this conclusion could reflect particular ecological or demographic conditions in the Oir basin and needs to be validated in other hydrographical and ecological contexts.
\end{abstract}

Key words: Salmo trutta / Sympatry / Genetic structure / Microsatellites

Résumé - Absence de différenciation génétique entre les truites anadromes et résidentes coexistant dans une rivière normande (l'Oir). Le niveau de différenciation génétique entre les truites anadromes et résidentes (Salmo trutta L.) coexistant dans une rivière normande (l'Oir) a été mesuré à l'aide de 15 locus microsatellites. Malgré une variabilité génétique importante, aucune différenciation génétique entre les deux formes n'a été décelée. Quatre souches domestiques ont été génotypées avec les mêmes locus. Une différenciation génétique hautement significative a été trouvée entre ces souches et les échantillons naturels permettant d'exclure un effet récent du repeuplement sur le secteur étudié. Les truites résidentes et anadromes de ce secteur semblent donc provenir d'une même unité de reproduction. Cette conclusion pourrait être propre à ce bassin et devra être confirmée sur d'autres bassins hydrographiques correspondant à d'autres contextes démographiques et écologiques.

\section{Introduction}

Anadromous and resident forms of Salmo trutta often live in sympatry in the Western Atlantic rivers of the native area. These two forms differ by their morphological, demographical and ecological characteristics (Nall 1938; Frost and Brown 1967; Campbell 1977; Baglinière et al. 2000) and have even been classified as different species in the past (Mills 1971; Elliott 1994). Despite clear differences in their life cycle, the extent of direct and indirect biological interactions in sympatry, through competition for food or space, and the extent of reproductive isolation between these two forms are still in discussion. The two forms may use the same locality for spawning during overlapping periods and are morphologically identical at the juvenile stage. Each form could have individuals

\footnotetext{
a Corresponding author: katia.charles@rennes.inra.fr
}

of the other form in their progeny (Skrochowska 1969; Ombredane et al. 1996; Debowski et al. 1999) and they interbreed to give fertile offspring (Frost and Brown 1967).

Migratory behaviour is a quantitative trait under partial genetic (Jonsson 1982; Palm and Ryman 1999) and environmental controls such as food (Nordeng 1983) and it is still today always difficult to prove and estimate their respective contribution. Existence of genetic differences between anadromous and resident forms have been reported for several salmonid species (Salmo salar: Verspoor and Cole 1989; Vuorinen and Berg 1989; Oncorhynchus nerka: Foote et al. 1989; Wood and Foote 1996; Salvelinus alpinus: Hindar 1986; Jonsson and Jonsson 2001; Klemetsen et al. 2002). In Salmo trutta, studies on genetic divergence between the migratory and nonmigratory forms have lead to different conclusions, from lack of genetic divergence (Guyomard et al. 1984; Hindar et al. 1991; Cross et al. 1992; Pettersson et al. 2001) to some degree 
of isolation (Krieg and Guyomard 1985; Krueger and May 1987; Skaala and Naevdal 1989). When they exist, such differences are difficult to interpret (Ferguson 1989; Northcote 1992) since they can also reflect isolation by distance or physical barriers (Jonsson 1982; Skaala and Naevdal 1989; Näslund 1993), or differential stocking effects on each of the ecotypes (Krieg and Guyomard 1985; Hauser et al. 1991; Hansen et al. 2000).

To date, most of the investigations on genetic differentiation between migratory and resident brown trout have been based upon protein data. Microsatellites have been scarcely used despite their higher potential to address questions related to ecotypes differentiation and stocking effects in trout (Nielsen and Fountain 1999; Hansen et al. 2001; Fritzner et al. 2001; Palm et al. 2003).

In this note, we report application of microsatellite markers to the analysis of genetic differentiation between sympatric anadromous and resident forms of Salmo trutta. Brown trout samples came from the River Oir, a tributary of the River Selune in Normandy (France).

\section{Materials and methods}

\subsection{Fish sampling}

Resident and migratory trout were collected in the Oir river, a tributary of the Selune river, which is $19 \mathrm{~km}$ long with a $85 \mathrm{~km}^{2}$ watershed area. Overlapping of spawning areas and periods have been recently shown in this basin (Charles et al. 2004).

The sampling area (Fig. 1) is a section of $14 \mathrm{~km}$, which includes $12 \mathrm{~km}$ of the main stream between the Cerisel station and the Moulin-du-Buat dam and the lower part $(2.2 \mathrm{~km})$ of the La Roche Brook, a tributary of the Oir river. This area was chosen because demographic data at the individual level and stocking information have been accumulated on its native brown trout population over 15 years. This allowed us to avoid or minimize potentially confounding effects of temporal and geographic variation or stocking in the interpretation of genetic differentiation between ecotypes. The study section is always accessible to the two forms of trout. Twenty-nine resident and twenty-six anadromous trouts were collected by electrofishing. All these fish had Pit-tag (Passive Integrated Transponder TROVAN system) which have been implanted at age $0+$ or $1+$ and proved that the fish originated from the Oir basin. All these fish were $2+$ or $3+$ when they were caught and belong to the 1996 or 1997 cohorts. The anadromous or resident status of each fish was based on the phenotype, the size and the identification of a marine phase by scale reading. Fish were anaesthetized with Phenoxy-ethanol and fin-clipped for genotyping. Fin-clips were stored in 95\% ethanol. Stocking has been stopped for more than ten years in the area studied. However, to assess a potential persistent impact of stocking in the wild population and discard the possibility that the Oir population is a recently introduced self-sustaining hatchery stock, four hatchery samples (Chauvet, Xertigny, Farcy, Fédération) were collected. Fédération and Farcy strains were the most frequently used to stock the River Oir in the past. The two others stocks come from east of France (Vosges) and were included to

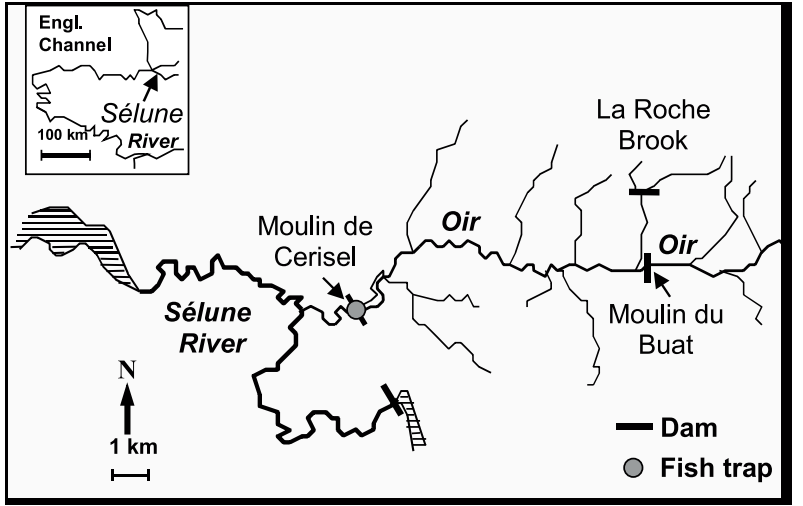

Fig. 1. Oir basin and sampling area.

obtain a more extensive description of genetic variation which can be found in hatchery stocks and to check if the assessment of the stocking impact remain valid when a larger spectrum of hatchery stocks is considered. This sampling design allowed us to exclude or take into account causes of differentiation such as non-indigenous origin of fish.

\subsection{Genotyping}

DNA was extracted from fin clips according to the proteinase K/Chelex extraction protocols (Estoup et al. 1996) and then stored at $-20{ }^{\circ} \mathrm{C}$. The six population samples were analysed with 15 microsatellite markers (Table 1). All loci were earlier assigned to distinct linkage groups and all are independent (Table 1). Procedures for PCR reaction and PCR product separation and visualisation have been described in Launey et al. (2003). Primer sequences, annealing temperature and $\mathrm{MgCl}_{2}$ concentration are given in Table 1 . Individuals with known genotypes were used as controls to allow comparison across gels.

\subsection{Statistical analyses}

Statistical significance of the genetic differentiation between anadromous and resident samples was tested with a hierarchical AMOVA using ARLEQUIN ver 2.000 (Schneider et al. 2000). This allowed to take into account the variation between 96 and 97 cohorts and to avoid confusion between ecotype and temporal differences. The GenETIX 4.03 (Belkir et al. 2000) program was used to estimate allele frequencies, number of alleles per locus, observed and expected heterozygosity. Departure from Hardy-Weinberg equilibrium and genetic differentiation between all pairs of populations were tested using GENEPOP 3.3 program (Raymond and Rousset 1995). To investigate the discriminating power of the 15 chosen loci and to reveal a possible hatchery contamination among the wild population, autoassignment and assignment tests were performed with the GENECLASS program (Cornuet et al. 1999). The "Bayesian method" and the "Leave one out" procedure were utilised. For the assignment test, the hatchery samples were used as baseline samples and the wild individuals as unknown file. 
Table 1. Primer sequences and Polymerase chain reaction (PCR) www.inra.fr/theses/these-integrale/Theses/gharbi/html/ these.html and pers. com.

\begin{tabular}{|c|c|c|c|c|c|c|c|c|}
\hline \multirow{2}{*}{ Locus } & \multirow{2}{*}{$\begin{array}{l}\text { Genbank } \\
\text { acces. } \mathbf{N}^{\circ}\end{array}$} & \multirow{2}{*}{ Forward primer } & \multirow{2}{*}{ Reverse primer } & \multirow{2}{*}{$\begin{array}{l}\text { Fluorescent } \\
\text { Label }\end{array}$} & \multicolumn{3}{|c|}{ PCR Conditions } & \multirow{2}{*}{$\begin{array}{l}\text { Linkage } \\
\text { group § }\end{array}$} \\
\hline & & & & & $\mathrm{T}\left({ }^{\circ} \mathrm{C}\right)$ & $\mathrm{MgCl2}(\mathrm{mM})$ & Migration (h) & \\
\hline BHMS396 & AF256714 & 5'-ССТGCCATCATCCAАCTC* & 5'-TCCACACCCAACATACTC & TAMRA & 52 & 1.5 & 1 & BT6 \\
\hline BHMS411 & AF256761 & 5'-CCAAGAGAAGATTAGTCATC* & 5'-CTCATCTGGGACAGGAAG & TAMRA & 52 & 1.5 & 2 & BT16 \\
\hline BHMS392 & AF256810 & 5'-CGTTCAATTCTCCCATATC* ${ }^{*}$ & 5'-GACAGATTTACCAGGAGC & TAMRA & 52 & 1.5 & 3 & ВТ 33 \\
\hline SSOSL417 & Z48598 & 5'-TTGTTCAGTGTATATGTGTCCCAT* & 5'-GATCTTCACTGCCACCTTATGACC & 6-FAM & 52 & 1 & 2 & BT35 \\
\hline SSOSL438 & Z49134 & 5'-GACAACACACAACCAAGGCAC* & 5'-TTATGCTAGGTCTTTATGCATTG & 6-FAM & 52 & 1.5 & 1 & BT13 \\
\hline SsaT47LEE & U86709 & 5'-CAACAGTGACAGCTGAAAGG & 5'-TCAGAGACGCACCTATTGG** & 6-FAM & 48 & 1 & 2 & BT9 \\
\hline BHMS276 & AF256792 & 5'-TGTTTGACGCCTCGTCTG* & 5'-CGCTGATCTTTGTGTAAGG & TAMRA & 52 & 1.5 & 3 & ВТз 30 \\
\hline BHMS321 & AF256743 & 5'-CTGTCATTCCCTTGGCAC* & 5'-GATGCTGCTAGGAGAGAG & 6-FAM & 52 & 0.8 & 1 & ВТ 31 \\
\hline BHMS349 & AF256746 & 5'-GCTGTGATTTCTCTCTGC* & 5'-AAAGGTGGGTCCAAGGAC & 6-FAM & 52 & 1 & $1 \mathrm{~h} 30$ & ВТ32 \\
\hline Str85INRA & AB001059 & 5'-GGAAGGAAGGGAGAAAGGT* & 5'-GGAAAATCAATACTAACAA & TAMRA & 50 & 1.5 & $1 \mathrm{~h} 30$ & BT2 \\
\hline StrAE43iilNRA & \# & 5'-0GTTGTGGGCTGAGTAATTGG* & 5'-СТССАСАTGСАTСТTACTAACC & TAMRA & 60 & 1 & $1 \mathrm{~h} 30$ & BT5 \\
\hline Str543INRA & AB001062 & 5'-CTTTCTCTTGCGATAGTACGG* & 5'-GTTTCTACAGTCAGCACAAGTC & Fluorescein & 51 & 1.2 & $1 \mathrm{~h} 30$ & BT17 \\
\hline StrBS131INRA & \# & 5'-CACATCATGTTACTGCTCC ${ }^{*}$ & 5'-CAGCCTAATTCTGAATGAG & 6-FAM & 50 & 1.5 & $1 \mathrm{~h} 30$ & BT25 \\
\hline StrT3-13INRA & \# & 5'-CCAGTTAGGGTTCATTGTCC* & 5'-CGTTACACCTCTCAACAGATG & 6-FAM & 52 & 1 & 2 & solo \\
\hline
\end{tabular}

* labeled primer, \# Estoup et al. (1998), § Gharbi K.

Table 2. Observed $(\mathrm{Ho})$ and Expected $(\mathrm{He})$ heterozygosities, number of alleles per population per locus $(a)$, total number of alleles per locus $(\mathrm{Ta})$. Sample sizes are given after population name.

\begin{tabular}{|c|c|c|c|c|c|c|c|c|c|c|c|c|c|c|c|c|}
\hline & & $\begin{array}{l}\text { StrAE43/ii- } \\
\text { INRA }\end{array}$ & $\begin{array}{l}\text { StrT3-13 } \\
\text { INRA }\end{array}$ & BHMS396 & BHMS392 & BHMS276 & BHMS411 & BHMS321 & $\begin{array}{c}\text { SsaT47 } \\
\text { LEE }\end{array}$ & BHMS349 & Ssos|417 & $\begin{array}{l}\text { Str85 } \\
\text { INRA }\end{array}$ & Ssos 1438 & $\begin{array}{l}\text { Str543 } \\
\text { INRA }\end{array}$ & $\begin{array}{c}\text { StrBS131 } \\
\text { INRA }\end{array}$ & $\begin{array}{c}\text { Mean } \\
\text { per locus }\end{array}$ \\
\hline \multirow[t]{3}{*}{ TRF Oir (29) } & $a$ & 4 & 16 & 15 & 16 & 17 & 16 & 8 & 17 & 13 & 12 & 6 & 4 & 9 & 7 & 11.4 \\
\hline & $H E$ & 0.438 & 0.921 & 0.867 & 0.918 & 0.909 & 0.894 & 0.705 & 0.923 & 0.885 & 0.837 & 0.818 & 0.587 & 0.646 & 0.797 & 0.796 \\
\hline & HO & 0.464 & 1.000 & 0.862 & 0.897 & 0.966 & 0.931 & 0.655 & 0.821 & 0.900 & 0.862 & 0.867 & 0.586 & 0.690 & 0.862 & 0.812 \\
\hline \multirow[t]{3}{*}{ TRM Oir (26) } & $a$ & 3 & 16 & 12 & 16 & 13 & 22 & 8 & 20 & 14 & 9 & 8 & 4 & 10 & 7 & 11.6 \\
\hline & $H E$ & 0.456 & 0.800 & 0.814 & 0.910 & 0.894 & 0.945 & 0.715 & 0.940 & 0.875 & 0.809 & 0.780 & 0.582 & 0.711 & 0.821 & 0.790 \\
\hline & HO & 0.500 & 0.846 & 0.923 & 0.923 & 0.962 & 1.000 & 0.692 & 0.923 & 0.769 & 0.720 & 0.731 & 0.731 & 0.654 & 0.808 & 0.799 \\
\hline \multirow[t]{3}{*}{ Farcy (35) } & $a$ & 5 & 12 & 14 & 14 & 12 & 18 & 7 & 15 & 15 & 8 & 7 & 6 & 9 & 8 & 10.7 \\
\hline & $H E$ & 0.648 & 0.858 & 0.874 & 0.903 & 0.672 & 0.898 & 0.762 & 0.889 & 0.836 & 0.835 & 0.774 & 0.741 & 0.824 & 0.759 & 0.805 \\
\hline & HO & 0.629 & 0.886 & 0.971 & 0.943 & 0.714 & 0.971 & 0.743 & 0.857 & 0.857 & 0.857 & 0.857 & 0.743 & 0.857 & 0.857 & 0.839 \\
\hline \multirow[t]{3}{*}{ Chauvet (15) } & a & 5 & 12 & 10 & 13 & 8 & 15 & 5 & 13 & 13 & 10 & 7 & 6 & 11 & 7 & 9.6 \\
\hline & $H E$ & 0.637 & 0.936 & 0.871 & 0.894 & 0.791 & 0.926 & 0.644 & 0.874 & 0.885 & 0.869 & 0.833 & 0.812 & 0.851 & 0.775 & 0.828 \\
\hline & HO & 0.600 & 1.000 & 1.000 & 0.867 & 0.733 & 0.933 & 0.733 & 0.933 & 0.733 & 0.800 & 0.857 & 0.800 & 0.867 & 0.600 & 0.818 \\
\hline \multirow[t]{3}{*}{ Xertigny (15) } & a & 4 & 9 & 10 & 11 & 9 & 14 & 5 & 13 & 8 & 9 & 7 & 4 & 9 & 6 & 8.4 \\
\hline & $H E$ & 0.591 & 0.890 & 0.812 & 0.920 & 0.867 & 0.936 & 0.669 & 0.929 & 0.848 & 0.869 & 0.807 & 0.687 & 0.851 & 0.812 & 0.820 \\
\hline & HO & 0.333 & 0.933 & 1.000 & 0.800 & 0.867 & 0.867 & 0.867 & 0.933 & 0.800 & 0.867 & 0.933 & 0.533 & 0.800 & 0.733 & 0.805 \\
\hline \multirow{4}{*}{ Fédération (35) } & $a$ & 5 & 14 & 11 & 15 & 11 & 16 & 9 & 19 & 16 & 9 & 8 & 6 & 12 & 8 & 11.4 \\
\hline & $H E$ & 0.432 & 0.893 & 0.873 & 0.899 & 0.804 & 0.903 & 0.830 & 0.904 & 0.865 & 0.627 & 0.824 & 0.703 & 0.859 & 0.627 & 0.789 \\
\hline & HO & 0.429 & 0.882 & 0.882 & 0.970 & 0.857 & 0.971 & 0.794 & 0.882 & 0.971 & 0.656 & 0.857 & 0.771 & 0.743 & 0.629 & 0.807 \\
\hline & $\mathrm{Ta}$ & 6 & 23 & 22 & 30 & 29 & 41 & 11 & 37 & 27 & 16 & 11 & 8 & 17 & 11 & 20.6 \\
\hline
\end{tabular}

\section{Results}

Genotypes were obtained for 15 loci since StrAE43INRA is duplicated. Multi-locus and Multi-population HardyWeinberg tests were not significant except for StrAE43/iINRA which systematically deviated from $\mathrm{H}-\mathrm{W}$ expectations and was excluded. AMOVA did not reveal any significant difference between 96 and 97 cohorts within each ecotype ( $p$-value = $0.132)$ and between ecotypes $(p=0.331)$ and most of the variation $(95.4 \%)$ occurred within samples. Cohorts of the same form were grouped together in subsequent analyses. The total number of alleles per locus ranged from 6 to 41 and expected heterozygosity from 0.789 to 0.828 (Table 2). Multi-locus tests for differentiation were highly significant between domesticated strains and the Oir population (two forms grouped). In addition, some alleles which were present at relatively high frequencies in domesticated stocks were not found in the natural population. This suggests that stocking impact was low or absent in the study area. The autoassignment test gave $81.41 \%$ of the individuals correctly reassigned to their population of origin. All the individuals were correctly reassigned to their group of origin: natural or hatchery. None of the natural 
individuals were reassigned to a hatchery population. Inside the two groups, natural and hatchery, most of the individuals were correctly assigned to their sample of origin. However, in the natural group for $50 \%$ of the individuals the test failed to choose between anadromous or resident form. Three individuals of the resident form were reassigned in the anadromous form and five of the anadromous form to the resident form.

\section{Discussion}

No significant genetic differentiation was found between anadromous and resident samples of Salmo trutta in the Oir basin. The AMOVA also showed that the differentiation between two successive cohorts was not significant, but much higher than divergence between forms. This illustrates the need to take into account or avoid temporal variation in such kind of studies as already pointed out (Palm et al. 2003). Our finding is in agreement with some other studies which did not report any genetic differentiation between sympatric anadromous and resident trout (Hindar et al. 1991; Cross et al.1992; Pettersson et al. 2001). Fergusson et al. (1995) reported nonsignificant Fst values between resident and anadromous brown trout for nuclear loci (microsatellites and allozymes) and significant Fst estimates based on mtDNA, indicating genetic differences between females of the two forms. These data could reflect some degree of reproductive barrier via females or, alternatively, the higher sensitivity of mtDNA to small population sizes. Sympatric anadromous and resident brown trout from Kerguelen archipelago were also found statistically undifferentiated (Guyomard et al. 1984). However, in this particular case, a lack of differentiation was not surprising since the two ecotypes have emerged from the same gene pool recently introduced in the island waters (Guyomard et al. 1984).

The Oir basin shows some peculiar characteristics which preclude any generalisation of the present findings. First of all, this small basin is accessible to the two forms on most of its length and, therefore, their spawning areas overlap considerably. Secondly, $80 \%$ of the anadromous component of the Oir basin are finnocks (Baglinière J.-L., com. pers.) which return to the river for spawning at moderate size while the resident trout have a good growth and can attain an adult size comparable to that of finnocks (Gouraud 1999). This characteristic could also facilitate the upstream migration and dispersion of the anadromous component and increase the probability of interbreeding between the two forms. On the contrary, the proportion of finnocks among sea trout is much lower in other Normandy rivers and larger size differences are found between the two ecotypes (Euzenat et al. 1999). These larger size differences are likely to reduce the extent of contact between the two forms for three reasons: (i) large anadromous fish will need larger spawning habitats located rather in the downstream parts of the large rivers; (ii) on the contrary, resident trouts might spawn rather in the upper parts of the watershed in relation with their smaller size; (iii) the differences might increase the impact of behavioural barrier related to size during spawning. This is expected to reduce gene flow between ecotypes and could result in some degree of differentiation between them.

Finally, although we were unable to detect any stocking impact in the Oir population, introgression between hatchery and natural populations has been frequently reported in Atlantic brown trout (Hauser et al. 1991; Hindar 1991b; Hansen et al. 2001; Palm et al. 2003). Furthermore, the impact of introgression can differ according to the river under investigation and the life strategy. Hansen et al. (2000) found that the effect was more important on the resident than on the anadromous component. On the contrary, Krieg and Guyomard (1985) found that the resident and the anadromous component of brown trout in the Orne river (which belongs to the same region as the Oir river) were substantially differentiated, but suggested that the anadromous component could be of an hatchery origin.

No differentiation between the anadromous and resident forms coexisting in the Oir basin was found in this study. However, such a finding could be related to the small size of the watershed which affect the adult size and the extent of sympatry and cannot be generalized. The present investigation should be extended to the headwaters of the Oir watershed where sea trout is not found and to larger Normandy basins where large anadromous and resident trouts coexist and which correspond to different ecological and demographic contexts.

Acknowledgements. The present study was financially supported by the Conseil Régional de Basse-Normandie. We are very grateful to the Conseil Supérieur de la Pêche river-keepers for their technical assistance in electrofishing, to R. Delanoë for his work at the Cerisel station and to F. Marchand for fish tagging. We wish to thanks Federation and Farcy hatchery staff who provided domesticated strain samples. M. Andriamanga was very helpful for laboratory assistance.

\section{References}

Barbat-Leterrier A., Guyomard R., Krieg F., 1989, Introgression between introduced domesticated strains and mediterranean native populations of brown trout (Salmo trutta L.). Aquat. Living Resour. 2, 215-223.

Baglinière J.L., Ombredane D., Marchand F., 2000, Critères morphologiques pour l'identification des deux formes (rivière et mer) de truite (Salmo trutta L.) présentes sur un même bassin. Bull. Fr. Pêche Piscic. 357/358, 375-386.

Belkir K., 2000, GENETIX 4.03, logiciel sous WindowsTM pour la génétique des populations. Laboratoire Génome, Populations, Interactions CNRS UMR 5000, Université de Montpellier II, Montpellier, France.

Campbell J.S., 1977, Spawning characteristics of brown trout and sea trout Salmo trutta L. in Kirk Burn, River Tweed, Scotland. J. Fish Biol. 11, 217-229.

Charles K., Roussel J.-M., Cunjak R.A., 2004, Estimating the contribution of sympatric anadromous and freshwater resident brown trout to juvenile production. Mar. Freshwater Res. 55, 185-191.

Cornuet J.-M., Piry S., Luikart G., Estoup A., Solignac M., 1999, New methods employing multilocus genotypes to select or exclude populations as origin of individuals. Genetics 153, 1989-2000.

Cross T.F., Mills C.P.R., De Courcy Williams M. 1992, An intensive study of allozyme variation in freshwater resident and andromous trout Salmo trutta L., in western Ireland. J. Fish Biol. 40, 25-32.

Debowski P., Glogowski J., Dobosz S., Robak S., 1999, Gill Na+-K+ ATPase activity and body silvering as indices of smoltification of hatchery-reared sea trout (Salmo trutta m. trutta L.). Arch. Ryb. Pol. 7, 245-256. 
Elliot J.M. 1994, Quantitative ecology and the brown trout. Oxford: Oxford University Press.

Estoup A., Largiadère C.R., Perrot E., Chourrout D., 1996, Rapid one-tube DNA extraction for reliable PCR detection of fish polymorphic markers and transgenes. Mol. Mar. Biol. Biotechnol. 5, 4, 295-298.

Estoup A., Rousset F., Michalakis Y., Cornuet J.M., Andriamanga M., Guyomard R., 1998, Comparative analysis of microsatellite and allozyme markers: A case study investigating microgeographic differentiation in brown trout (Salmo trutta). Mol. Ecol. 7, 339-353.

Euzenat G., Fournel F., Richard A., 1999, Sea trout (Salmo trutta L.) in Normandy and Picardy. In: Baglinière J.-L., Maisse G. (Eds.), Biology and Ecology of the brown trout and sea trout, Praxis, pp. 175-205.

Ferguson A., 1989, Genetic differences among brown trout, Salmo trutta L., stocks and their importance for the conservation and the management of the species. Freshwater Biol. 21, 35-46.

Ferguson A., Taggart J.B., Prodöhl P.A., McMeel O., Thompson C., Stone C., Mc Ginnity P., Hynes R.A., 1995, The application of molecular markers to the study and conservation of fish populations with special references to Salmo. J. Fish Biol. 47, 103-126.

Foote C.J., Wood C.C., Withler R.E., 1989, Biochemical genetic comparison of sockeye salmon and kokanee, the anadromous and nonanadromous forms of Oncorhynchus nerka. Can. J. Fish. Aquat. Sci. 46, 149-158.

Fritzner N.G., Hansen M.M., Madsen S.S., Kristiansen K., 2001, Use of microsatellite markers for identification of indigenous brown trout in a geographical region heavily influenced by stocked domesticated trout. J. Fish Biol. 58, 1197-1210.

Frost W.E., Brown M.E., 1967, The Trout. London, Collins.

Gouraud V., 1999, Étude de la dynamique de populations de truite commune (Salmo trutta L.) à l'aide d'un modèle déterministe. Application sur un bassin Bas-Normand et sur un bassin Pyrénéen. Thèse ENGREF Centre de Paris.

Guyomard R., Grévisse C., Oury F.X., Davaine, P., 1984, Évolution de la variabilité génétique inter et intra-populations de populations de Salmonidés issues de mêmes pools géniques. Can. J. Fish. Aquat. Sci. 41, 1024-1029.

Hansen M.M., Ruzzante D.E., Nielsen E.E., Mensberg K.-L., 2000, Microsatellite and mitochondrial DNA polymorphism reveals life-history dependent interbreeding between hatchery and wild brown trout (Salmo trutta L.). Mol. Ecol. 9, 583-594.

Hansen M.M., Ruzzante D.E., Nielsen E.E., Mensberg K.-L., 2001, Brown trout (Salmo trutta L.) stocking impact assessment using microsatellite DNA markers. Ecol. Appl. 11, 148-160.

Hauser L., Beaumont A.R., Marshall G.T.H., Wyatt R.J., 1991, Effects of trout stocking on the population genetics of landlocked brown trout, Salmo trutta L., in the Conwy River system, North Wales, U.K. J. Fish Biol. 39 (suppl. A), 109-116.

Hindar K., 1986, Genetic differentiation among local populations and morphotypes of Artic charr, Salvelinus alpinus. Biol. J. Linn. Soc. 27, 269-285.

Hindar K., Jonsson B., Ryman N., Stahl G., 1991a, Genetic relationships among landlocked, resident and anadromous Brown trout, Salmo trutta L. Heredity 66, 83-91.

Hindar K., Ryman N., Utter F., 1991b, Genetic effects of cultured fish on the natural fish populations. Can. J. Fish Aquat. Sci. 48, 945-957.

Jonsson B., 1982, Diadromous and resident trout Salmo trutta L.: Is their difference due to genetics? Oikos 38, 297-300.

Jonsson B., Jonsson N., 2001, Polymorphism and speciation in Arctic charr. J. Fish Biol. 58, 3, 605-638.
Klemetsen A., Elliott J.M., Knudsen R., Sorensen P., 2002, Evidence for genetic differences in the offspring of two sympatric morphs of Arctic charr. J. Fish Biol. 60, 933-950.

Krieg F., Guyomard R., 1985, Population genetics of French brown trout (Salmo trutta L.): large geographical differentiation of wild populations and high similarity of domesticated stocks. Génét. Sélect. Evol. 17, 225-242.

Krueger C.C., May B. 1987, Stock identification of naturalized brown trout in Lake Superior Tributaries: Differentiation based on allozymes data. Trans. Am. Fish. Soc. 116, 785-794.

Launey S., Krieg F., Haffray P., Bruant J.S., Vannier A., Guyomard R., 2003, Twelve new microsatellite markers for gilted seabream (Sparus aurata L.): Characterization, polymorphism and linkage. Mol. Ecol. Notes 3, 457-459.

Mills D., 1971, Salmon and Trout: a resource, its ecology, conservation and management. Oliver Boyd Edn.

Näslund I., 1993, Migratory behaviour of brown trout, Salmo trutta L.: Importance of genetic and environmental influences. Ecol. Freshwater Fish 2, 51-57.

Nielsen J.L., Fountain M.C., 1999, Microsatellite diversity in sympatric reproductive ecotypes of Pacific steelhead (Oncorhynchus mykiss W.) from the Middle Fork Eel River, California. Ecol. Freshwater Fish 8, 159-168.

Nordeng H., 1983, Solution to the "Char problem" based on Arctic Char (Salvelinus alpinus) in Norway. Can. J. Fish. Aquat. Sci. 40, 1372-1387.

Northcote T.G., 1992, Migration and residency in stream Salmonids - some ecological considerations and evolutionary consequences. Nordic J. Freshwater Res. 67, 5-17.

Ombredane D., Siegler L., Baglinière J.-L., Prunet P., 1996, Migration et smoltification des juvéniles de truites (Salmo trutta) dans deux cours d'eau de Basse-Normandie. Cybium 20, 3, 27-42.

Palm S., Ryman N., 1999, Genetic basis of phenotypic differences between transplanted stocks of brown trout. Ecol. Freshwater Fish 8, 169-180.

Palm S., Dannewitz J., Järvi T., Petersson E., Prestegaard T., Ryman N. 2003, Lack of molecular genetic divergence between searanched and wild trout (Salmo trutta). Mol. Ecol. 12, 2057-2071.

Pettersson J.C.E., Hansen M.M., Bohlin T., 2001, Does dispersal from landlocked trout explain the coexistence of resident and migratory trout females in a small stream? J. Fish Biol. 58, 487-495.

Raymond M., Rousset F., 1995, GENEPOP (version 1.2): Population genetics software for exact tests and ecumenism. J. Hered. 86, 248-249.

Schneider S., Roessli D., Excoffier L., 2000, Arlequin vers. 2.000. http://lgb.unige.ch/arlequin/.

Skaala Ø., Nævdal G., 1989, Genetic differentiation between freshwater resident and anadromous brown trout, Salmo trutta L., within watercourses. J. Fish Biol. 34, 597-605.

Skrochowska S., 1969, Migrations of the sea-trout (Salmo trutta L.), brown trout (Salmo trutta M. fario L.) and their crosses. Part IV. General discussion of results. Pol. Arch. Hydrobiol. 16, 29, 181-192.

Verspoor E., Cole L.J., 1989, Genetically distinct sympatric populations of resident and andromous Atlantic salmon, Salmo salar. Can. J. Zool. 67, 1453-1461.

Vuorinen J., Berg O.K., 1989, Genetic divergence of anadromous and nonanadromous Atlantic Salmon (Salmo salar) in the River Namsen, Norway. Can. J. Fish. Aquat. Sci. 46, 406-409.

Wood C.C., Foote C.J., 1996, Evidence for sympatric genetic divergence of anadromous and non anadromous morphs of Sockeye salmon (Oncorhynchus nerka). Evolution 50, 3, 1265-1279. 